Cultures de bêtes... Outils qui pensent?

\title{
Comparaisons et raisons
}

Commentaires sur une petite bibliographie animalière

\section{François Sigaut}

\section{OpenEdition}

\section{Journals}

Édition électronique

URL : https://journals.openedition.org/tc/583

DOI : $10.4000 /$ tc.583

ISSN : 1952-420X

Éditeur

Éditions de l'EHESS

\section{Édition imprimée}

Date de publication : 1 novembre 1995

ISSN : 0248-6016

Référence électronique

François Sigaut, "Comparaisons et raisons », Techniques \& Culture [En ligne], 23-24 | 1995, mis en ligne le 09 décembre 2005, consulté le 29 septembre 2022. URL : http://journals.openedition.org/tc/583 ;

DOI : https://doi.org/10.4000/tc.583

Ce document a été généré automatiquement le 29 septembre 2022.

Tous droits réservés 


\section{Comparaisons et raisons}

Commentaires sur une petite bibliographie animalière

François Sigaut 